University of Nebraska - Lincoln

DigitalCommons@University of Nebraska - Lincoln

Faculty Publications in Food Science and Technology

Food Science and Technology Department

January 2006

\title{
Secretion of Food Allergen Proteins in Saliva
}

\section{S. J. Maleki}

USDA-Agricultural Research Service, soheila.maleki@ars.usda.gov

H. Cheng

USDA-Agricultural Research Service

B. Perelman

Immunology and Allergy, St. Michael's Hospital, Toronto, ON, CANADA

S. Hefle

University of Nebraska-Lincoln

P. Vadas

Immunology and Allergy, St. Michael's Hospital, Toronto, ON, CANADA

Follow this and additional works at: https://digitalcommons.unl.edu/foodsciefacpub

Part of the Food Science Commons

Maleki, S. J.; Cheng, H.; Perelman, B.; Hefle, S.; and Vadas, P., "Secretion of Food Allergen Proteins in Saliva" (2006). Faculty Publications in Food Science and Technology. 35.

https://digitalcommons.unl.edu/foodsciefacpub/35

This Article is brought to you for free and open access by the Food Science and Technology Department at DigitalCommons@University of Nebraska - Lincoln. It has been accepted for inclusion in Faculty Publications in Food Science and Technology by an authorized administrator of DigitalCommons@University of Nebraska - Lincoln. 
S. J. Maleki ${ }^{1}$, H. Cheng ${ }^{1}$, B. Perelman ${ }^{2}$, S. Hefle ${ }^{3}$, P. Vadas ${ }^{2} ;{ }^{1}$ Food Allergy Unit, USDA-Agricultural Research Service, New Orleans, LA, 2Immunology and Allergy, St. Michael's Hospital, Toronto, ON, CANADA, ${ }^{3}$ Department of Food Science \& Technology, University of Nebraska, Lincoln, NE.

RATIONALE: Peanut proteins were found to be secreted in 50\% of lactating women's breast milk. We wanted to develop a testing method to predict the secretion of peanut protein in breast milk. The secretion of food protein in saliva was hypothesized to be a possible predictor of secretion of foods in breast milk following ingestion.

METHODS: Non-allergic volunteers, some lactating, ingested 50 grams of either whole peanuts, peanut milk or cow's milk and various immunoassays were utilized to analyze for the presence of peanut or cow's milk proteins in saliva and breast milk. Saliva and breast milk samples were subjected to SDS-PAGE, Western blot and ELISA analysis with anti-raw and roasted peanut and anti-alpha-casein antibodies and pooled serum IgE from peanut allergic individuals.

RESULTS: Peanut protein levels in breast milk were undetectable using Western blot analysis and inconsistent with ELISA analysis. However, peanut proteins around 20 and $30 \mathrm{kDa}$ that reacted with anti-roasted peanut antibody were detected, 6-18 hours following ingestion, in saliva of different individuals. An $18 \mathrm{KDa}$ band that reacts with anti-alpha casein antibody was also detected in saliva 6-18 hours following ingestion.

CONCLUSIONS: Secretion of food allergen proteins or peptides in saliva several hours following ingestion may have important implications for delayed allergic reaction by sensitive patients. Also, due to the fact that these proteins or peptides survive digestive enzymes, become absorbed into the blood stream and are subsequently secreted in biological fluids may indicate that they are most likely the sensitizing or tolerizing agent within an allergic food.

Funding: National Peanut Board, USDA 